\title{
Ecumene of the Logos: Theoretical Affinities Between Italian and Russian Ontologism
}

\author{
Marek Kita ${ }^{1}$ (D)
}

Published online: 29 June 2020

(c) The Author(s) 2020

\begin{abstract}
The topic of this article is the convergence of the fundamental theoretical intuitions of two independent currents of Christian philosophy at the turn of the nineteenth and twentieth centuries. Italian Catholic spiritualism and the internally diversified current of the Russian religious philosophical Renaissance proved to be convergent in their ontological realism based on the metaphysics of cognition. This consonance undermines the stereotype about the total difference between the Russian Orthodox and the Western Catholic mentality. The article tries to show that these two denominations both drew inspiration from the Patristic heritage and that, contrary to all appearances, Russian religious philosophy owes much to the Augustinian tradition. The paper reminds the discovery of this convergence made by Vladimir Ern, and discusses certain elements of the teachings of Vladimir Solovyev and Evgenii Troubetzkoy in comparison with the basic philosophical intuitions of the Italian philosopher Antonio Rosmini.
\end{abstract}

Keywords Italian ontologism · Russian ontologism $\cdot$ Christian philosophy · Antonio Rosmini · Vladimir Ern · Ecumenism · Logos · Augustinism · Evgenii Troubetzkoy · Vladimir Solovyev

\section{Introduction}

The theoretical affinity of the Italian Catholic spiritualism of Vincenzo Gioberti (1801-1852) and Antonio Rosmini (1797-1855) with the Orthodox "ontological" philosophy typical of the heritage of Gregory Skovoroda (1722-1794) and Vladimir Solovyev (1853-1900) has been noticed by the passionate apologist of Russian philosophical culture, Vladimir Ern (1882-1917). His discovery-fascinating from a historical and philosophical point of view and interesting from the perspective of ecumenical studies-was made during modern Russian disputes about

Marek Kita

marek.kita@upjp2.edu.pl

1 Pontifical University of John Paul II, Kraków, Poland 
the nature of their national philosophy and its attitude towards European culture, on the grounds of a kind of prolongation of the controversy between "Westernizers" and "Slavophiles" - a controversy initiated by the philosophical letters of Pyotr Chaadayev (1794-1856) (see: Sivak 2007, p. 25). At the end of the period of the Russian Empire, between the revolutionary shock of 1905 and the catastrophe of 1917, a group of philosopher-ontologists gathered around the publishing house Put' (The Way) were engaged in a polemic with the Neo-Kantians.

At that time, the aforementioned Vladimir Ern was waging the most fervid "struggle for the Logos" — as per the title of his famous collection of articles (Ern 1911) — seeing in logos "a battle cry which calls philosophy to turn from scholasticism and abstractness towards life, while not raping life with schemes, but, on the contrary, being attentive to it, becoming an inspired and sensitive interpreter of its divine meaning" (Ern 2016). Ern, a zealot and defender of the Orthodox philosophy, contemplating existence against the onslaught of Western epistemologism, made an "ecumenical"1 discovery that fundamentally undermined the thesis of an "essential difference between Russian and Western mentalities" (Walicki 2005, p. 173).

During his studies in Italy in 1911-1915, Ern was delving into the philosophical legacy of Rosmini and Gioberti. In 1914, Ern published his master's thesis entitled Rosmini and His Theory of Knowledge (Rozmini i ego teorija znanija) (Ern 1914) and, in 1916, he published his doctoral thesis on Vincenzo Gioberti, The Philosophy of Gioberti (Filosofija Dzhoberti) (Ern 1916). As a result, he became convinced that their thought (undeservedly ignored by most scholars) ${ }^{2}$ is not only an "immense and independent branch of post-Kantian philosophy" (Ern 1915, p. 242), but also deserves the special attention of Russian thinkers precisely because of their strong intellectual affinity.

\section{Ecumenism in Philosophy?}

The Greek term logos evokes associations with classical Hellenic philosophy (the cosmic reason of Heraclitus and the reason-providence of the Stoics) as well as with the theological philosophy of Philo of Alexandria and Christian theology (the Wordlight of John the Evangelist, identified with Christ as the Son of God). In the history of European thought, Logos Christology was a stimulating factor for the development of a universal philosophical paradigm assuming the rationality of the universe,

\footnotetext{
1 In this article, I use the term "ecumene" in its etymological sense to describe a community sharing the same basic philosophical paradigm. In turn, the term "ecumenism" is used to signify the affirmation of the said community despite some diversity of intellectual traditions. However, associations with theological ecumenism are intentional, because the philosophical currents discussed in the article developed in religious contexts. The theoretical affinity of philosophical currents rooted in different denominational cultures is also relevant for proper theological ecumenism. This will be discussed in the second section of the article.

${ }^{2}$ Unfortunately, this tendency to ignore the achievements of Italian ontologism also persisted at a later stage, which was, to some extent, influenced by theological reservations from the Neo-Thomist community and the Holy Office itself. These reservations will be further discussed below.
} 
the reasonability of reality (as Jaroslav Pelikan notes in his book Jesus Through the Centuries 1985).

We also know that for thinkers of the Russian philosophical and religious Renaissance, their affirmation of the living logos of being was the basis of "mystical realism," as Berdyaev puts it (Berdyaev 1907, p. 2). This worldview, then called ontologism (because it was the opposite of post-Kantian gnoseologism), understood logos as a subtle epiphany of the ontological truth, of the truth identical with being. Russian ontologism was undoubtedly an element of Christian philosophy, but by no means a non-confessional one, free from the schemes of school theology, as was emphasized by a Polish researcher of this philosophy (Mazurek 2008, pp. 10-11). Exactly this kind of reflection, philosophical and not dogmatic, may truly enrich the pluralistic forum for the exchange of ideas (Mazurek 2008, pp. 11-12). It seems that Italian Catholic spiritualism with its version of ontologism can be similarly enriching for modern philosophical debates. But is it not an abuse to link the study of the theoretical affinity of Italian and Russian ontologism with ecumenism?

The theme of ecumenism may seem unrelated to philosophy, as ecumenism in the strict sense refers to the entirety of intellectual, spiritual, and practical effort aimed at eliminating confessional divisions while respecting the pluralism of theological, liturgical, and canonical traditions. However, philosophy both contributes to theology and benefits from theological wisdom. After all, dogmatic formulations have been elaborated with the aid of philosophical concepts, while theological discoveries significantly influenced philosophy_ancient, modern, and contemporary-, broadening the scope of issues covered by ontological, anthropological, ethical, and historiosophical reflection. As we read in John Paul II's encyclical Fides et ratio, when considering the matters proposed by revelation and theology in accordance with the methodology appropriate to their field, philosophers "have not become theologians," they do not lose their professional identity (John Paul II 1998, §. 76).

Presumably, a philosopher does not need to encroach upon a territory that is not his own when studying the fundamental affinities of philosophical movements evolving in separate theological and cultural Christian environments. Such environments may turn out to be, if we refer to the Greek etymology, like "flats in a shared home" (oikos), i.e., like one single oikoumene. . We must add, however, that, in the case of religious philosophy, and in particular the Russian one, the borderline between philosophy and religion is vague and arbitrarily drawn. One could speak of a kind of perichoresis of the philosophy of religion and of fundamental theology.

In his ecumenically oriented lectures at the theological faculty of Lyon, ${ }^{3}$ Paul Evdokimov interpreted this specificity of "theological philosophy" as follows: "as B. Vicheslavtzev correctly says: 'We always think in relation to the Absolute.' This link confers to any philosophical reflection the religious dimension" (Evdokimov 1988 , p. 84). The intuitivism and ontologism of such a philosophy correspond to the biblical gnoseology of "knowing with the heart" and to the old Hebrew "poetic

\footnotetext{
3 The result of these lectures (delivered at the turn of February and March 1966), the book entitled $\mathrm{La}$ connaissance de Dieu selon la tradition orientale (first edition: 1968), contains a chapter devoted to Russian religious philosophy.
} 
metaphysics," while restoring the dimension of "spiritual exercise" to philosophical reflection, which philosophy had at its Hellenic origins, as Pierre Hadot once reminded (Hadot 1981). As Werner Jaeger noticed, the famous Dialogus cum Tryphone Iudaeo by Justin Martyr begins with a scene in which a rabbi invites a man dressed in the philosopher's cloak to talk about God (Jaeger 1985, p. 31). This is a clear testimony that the ancients considered the issue of "natural theology" as an integral part of philosophy. Also, the history of later European thought reveals the phenomenon of Christian philosophy in the broad sense of the word, i.e., such currents of reflection that "would not have happened without the direct or indirect contribution of the Christian faith" (John Paul II 1998, §. 76), namely addressing issues of theology derived from revelation. ${ }^{5}$

At the same time, however, Russian religious philosophy aspires to be a renewed sort of "Neo-Patristics in the context of the modern world" (Evdokimov 1988, p. 93) and thus an updated, strictly Christian reflection, although (as it has already been mentioned) with a loose approach to traditional catechismal views of the doctrines. This reflection, faithful to the contemplative logos of ancient philosophers and Church fathers, is opposed to abstract ratio, the modern rationalist reason.

In the extreme case of this opposition, Western rationalism - the "thinking about thinking," which deprives reality of its being — has been deemed a legitimate child of Latin Christianity. The adversaries of extreme rationalism have accused the Latin tradition of cutting themselves off from their life-giving roots, from the Hellenicbiblical wisdom of the first centuries. Meanwhile, theoretical affinities between Italian and Russian ontologism prove that at least certain currents of thought of Latin Christianity belong to the ecumene of $\log o s$ as a contemplative intellect, i.e., as a "cordial" reason rooted in the heart as understood biblically (i.e., at the core of the self as the common center of reasoning, intuition, will, and feelings). It would also be the ecumene of logos as an ontological form of thinking, common to the great Greek tradition and Christian Patristics.

The present article is therefore about ecumenism in the broad sense, although it is also related to and contributive to ecumenism in the narrow sense. Its aim is to call the reader's attention to a deep intellectual and spiritual commonality-in all its variety at the core of the "sororal" traditional cultures of Eastern and Western Europe. Vladimir Ern described this commonality as follows:

It is absolutely unquestionable that between Italian ontologism and the original currents of Russian philosophical thought there are features of great internal similarity [...]. The features of the unexpected internal affinity once again con-

\footnotetext{
4 The expression "poetic metaphysics" is used by Claude Tresmontant in his important (though debut) work Essai sur la pensée hébraïque (Tresmontant 1953), in which he discusses the philosophical paradigm of biblical thought. It is worth noting, however, and with all due respect to Tresmontant's positive presentation of the biblical worldview, that it is not entirely justified to strictly oppose this worldview with the fundamental convictions of the Greek philosophical tradition. In his valuable study, Tresmontant seems to put a polemical emphasis on differences over the insight of the "ecumenist" in the broad sense of the term.

5 We can also read there that the expression "Christian philosophy" in this case "in no way intends to suggest that there is an official philosophy of the Church" (John Paul II 1998, §. 76).
} 
firm the idea that the way of the spirit remains one for all mankind regardless of national peculiarities, and that there is only one way for different nationalities to meet in a unity of a higher order-metaphysically deepen their consciousness and return to the living ontological roots of their being. (Ern 1915, pp. 249-250)

\section{Ecumene of a "Right Reason"}

The congeniality of the Russian and Italian versions of modern ontologism is all the more fascinating due to the fact that there are no traces of contact between representatives of the two intellectual circles during the development of their reciprocal doctrines. Thus, from the perspective of Christian philosophy, one can probably speak of a commonality of "right reason" (orthos logos). This logos "intuits and formulates the first universal principles of being" (John Paul II 1998, §. 4) and is a source of correct philosophical enquiry, which in turn takes precedence over specific philosophical systems. This is the reason why Christian thinkers of the above-mentioned currents argued against modern rationalism. They were opting for an integral intellect penetrating into reality as opposed to the reduced reason, or ratio, operating in the sphere of abstraction and trapped in a world of concepts.

In Ern's view, an alternative to abstract rationalism and epistemologism, according to which there is no contact with being and where the mind lives in a world of its own ideas and sensations, was the contemplative "logism" and ontologism, according to which the mind assimilates the actual meaning (logos) of things and is immersed in ontologically understood truth, in the element of absolute logos. In his essay opening the Bor'ba za Logos (Struggle for Logos) volume, Ern wrote:

The universe, the cosmos, is the unveiling and revelation of the Word existing from the beginning. As this unveiling and revelation, the world is in its most secretive depth "logical," i.e., consistent with and commensurate to logos, and every detail and every event in this world is a hidden thought, a secret movement of the divine Word that permeates everything. Logos as the principle of human cognition is not another logos different from the essentially divine logos. It is the same logos, but in various degrees of realization. (Ern 1911, p. 82)

Our cognition and comprehension of reality comes from being illuminated by "the true light that gives light to everyone" (John 1: 9), from secret participation (in a panentheistic way) in the absolute intellect.

The prologue to the Fourth Gospel is about the Logos of God as an expression of the Absolute and as the Word defining the meaning of created reality. In a commentary to this prologue, Vladimir Solovyev wrote: "This integrality is self-subsistent in the unchangeable quietude of eternity; it reveals itself in the unitive meaning of

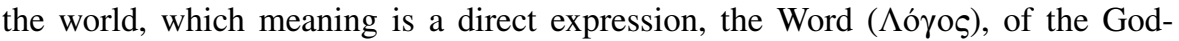
head; it is God, God revealing himself and moving in the world" (Solovyev 1937, p. 98). Therefore, the meaning of the world, understood as cosmos (i.e., as order, 
according to the Greek etymology), is to reflect the harmony of the being of its creator through the symphonic unity of created beings in their diversity. This meaning "shines" (i.e., manifests itself) in the unconscious life of nature through the darkness of the universal struggle for survival ("The light shines in the darkness," John 1: 5), and "shines" forth in human consciousness as the "idea of general unity" (Solovyev 1937, p. 103), integrating phenomena into a coherent whole.

The concept of illumination of our consciousness was further developed by a direct disciple of Solovyev, Evgenii Troubetzkoy (1863-1920). Troubetzkoy pointed out that the intuitively postulated objective meaning understood as "universally meaningful content of thought" that determines the significance of sensations is a necessary condition of consciousness (Troubetzkoy 1994, p. 6). In fact, " "to realize [soznat'] something' precisely means to give it the form of a universally meaningful thought" (Troubetzkoy 1994, p. 6). The adjustment of the mind to the objective meaning of phenomena, i.e., the truth of being manifesting itself (which truth, transcending anyone's particular psychological consciousness, turns out to be not only "logical" but also "ontological"), is about the attachment of a psychological subject to some supra-psychological consciousness, whose content must be the aforementioned meaning (understood as intellectual content) (Troubetzkoy 1994, p. 14). According to both the Latin and Russian etymology, consciousness (con-scientia, so-znanie, "with-knowledge") is our participation in the knowledge possessed by the absolute intellect (Troubetzkoy 1994, p. 21).

Conscious cognition of the surrounding world generates a disagreeable dissonance due to the fact that the life of nature and humanity remains entwined with the circle of the murderous struggle for survival, which is always lost in advance. It cannot be overlooked that "the whole world is under the control of the evil one" (1 John 5: 19); life is often not logical, but rather absurd. However, the meaning-logos understood positively, not only as a "universally meaningful thought" but also as a "positive and universally significant value," manifests itself in this dissonance, precisely in the form of an overwhelming lack (Troubetzkoy 1994, p. 6).

Even the realization of the absurdity and imperfections of reality proves that the mind is rooted in the perfect meaning that we intuitively know and instinctively seek everywhere. Just as our recognition that a melody is out of tune proves that we have a sense of harmony, our awareness of an imbalance in the harmony of the world indicates the existence of an intuition of absolute harmony (Troubetzkoy 1994, pp. 34-35). The intuition of absolute logos is a hidden foundation of our orientation in the world, a subtle background for the dissonances that we notice. Our intuitive assessment of reality is an epiphany of meaning as the inner light of the mind, as the truth that dwells inside a human being.

As for the Italian version of ontologism, in Nuovo saggio sull'origine delle idee (New Essay on the Origin of Ideas), Rosmini carefully analyzes the act of judging, which constitutes cognition, reveals in each judgment its "material" and "formal" element. The "material" element is the sensation of what is perceived and the "formal" element is the idea of existence. The original synthesis of these elements (the "primal and synthetical judgment," prior to Kant's analytical judgments and making them possible) results in the perception of a specific thing and allows us to create the concept of this thing (see: Rosmini 2001, p. 310). This original synthesis of the 
content of the perception and the fundamental category of existence is - according to a contemporary German researcher - a Rosminian alternative of a "synthetical a priori judgment" (see: Krienke 2006, p. 47). Thus, Rosmini proved that the idea of being - the basis of all judgment-is innate ${ }^{6}$ and that the categories of quantity, quality, relation, and modality condition not so much the intellectual perception (experience) as the existence of things external to the cognizing subject (Rosmini 2001, pp. 289-290). Conversely, the original and fundamental form of the human mind, to which the multitude of Kantian forms can be reduced, remains the idea of being in general (see: Rosmini 1883, pp. 370-382). It is an absolutely pure form, essentially objective, an idea so simple that it is irreducible to something simpler and is at the same time infinitely fertile, conditioning every act of thinking, always having a reference to being. In the introduction to a collection of his works dealing with the nature of human knowledge, Rosmini characterized the idea of being as "the luminous point from which emanates the clear light of certainty and of truth for all other cognitions" (Rosmini 2001, p. 412).

This ontological revelation at the very sources of gnoseology was associated, for Rosmini, with the traditional concept of illumination, connected with the Christology of the Logos. In the preface to his fundamental work Nuovo saggio sull'origine delle idee (New Essay on the Origin of Ideas), the thinker declared his intention to invite readers "to observe their inner thoughts and feelings, the things they already know naturally, even though habitually they do not reflect on them" (Rosmini 2001, p. 1). With his Nuovo saggio, Rosmini wanted to answer the question "What is the light of reason?" (Rosmini 2001, p. 1). Reflection on this specific lumen mediating between the truth and human intellect, as Rosmini put it referring to a phrase by Dante, ${ }^{7}$ led to the very "source of truth within us" (Rosmini 2001, p. 5) and to the discovery of the seed of the philosophia vera, with unity and totality as its characteristics. The idea of being as that which is identical with truth (since what exists, is what is true), ${ }^{8}$ brings order to both cognition and existence, showing man his position within the universal scheme of things (Rosmini 2001, p. 6). To Rosmini, this idea of being is also the result of the natural subconscious perception of the supranatural factor influencing us, the factor fully revealed in Christianity. The Italian thinker stated in the patristic spirit that Christianity and philosophy share the same principle, namely truth, which manifests itself in philosophy as "the natural

\footnotetext{
6 "In other words, myself, who is on the one hand modified by sensitivity through which I feel the sensible agent acting upon me, am the same subject who, on the other hand, possesses the idea of existence in my intellect" (Rosmini 2001, p. 293).

7 See: Rosmini (2001, p. 2). Rosmini referred to the words put by the author of Commedia in the mouth of Virgil, announcing the explanation of theological doubts to the wanderer through Beatrice, "che lume fia tra l'vero e l'intelletto" (who betwixt truth and the intellect infuses light) (Aligheri 1858, p. 188). The figure of Dante's ideal woman, who, according to a twentieth-century commentator, symbolizes, perhaps, the fifth degree of mind-soul ascent towards God in line with the doctrine of Saint Bonaventure (see: Anderson 2010, p. 346), and "higher knowledge" from the intellectus sphere, not ratio, according to the distinction of Aquinas (see: Anderson 2010, p. 410). For Rosmini, it is associated with the Aquinatian light of the active intellect, which will be discussed later.

${ }^{8}$ In the third book of Nuovo saggio, Rosmini states that, "As soon as ideal being comes to be considered in its various relations, it takes different names expressive of those relations. If considered as the source of our acquired knowledge, it takes the name of truth" (Rosmini 1884, p. 339).
} 
light of the mind (initial truth)," i.e., as an idea, and which, in Christianity, occurs as "truth in its absolute fullness: first, subsistent truth," i.e., as the dynamic Word of God (Rosmini 2001, p. 8). Thus, philosophia vera is propaedeutic to vera religio: "We will be more fully open to worship and faith the further we move away from error and the more we recognise and cherish even the 'preliminary outline' of natural Christianity (if I may use that term) which in us is natural truth and a veiled form of the divine Word [un crepuscolo [...] del Verbo divino], as I would be tempted to call it" (Rosmini 2001, p. 9). ${ }^{9}$

In his comment to the above-mentioned statement, Rosmini recalled the verse inspiring Saint Augustine from the prologue of the Fourth Gospel on "the true light that enlightens every person by his coming into the world" (John 1: 9). ${ }^{10}$ Evidently, for Rosmini the principle constituting our intellect, i.e., the intellect of a human being as animal rationale, also makes us anima naturaliter christiana. We are by nature inclined to believe the Word of God, because it is the manifestation of it that creates our intellect. The foundation of our intellect is the Word (Logos) through which all the things were made (cf. John 1: 3). Gnoseology, in its very foundations, opens itself to metaphysics, which in turn naturally opens itself to religion. As Ern stated, we are dealing with "logism," an attitude that affirms realism thanks to the ontological understanding of truth, ultimately grounded in supernaturalism. The human mind, thanks to the logos constituting it ("the crepuscule of divine Logos") is capax Dei, rationality leads to faith.

\section{Under the Auspices of the Alexandrian School and Saint Augustine}

The same orientation of Russian and Italian ontologism towards the intellectual light of the truth of existence, towards the logos of being, evidently followed in both cases from their borrowing from the tradition of the ancient Alexandrian School. In new circumstances, in spite of the then "sophists" and in critical dialogue with the "gnostics" of that time, modern ontologists have worked out an updated form of "orthodox gnosis." As in the case of the Alexandrian School, this modern orthodox gnosis was "philosophical" Christianity, but not in the sense of a reduction of faith to philosophy, even if understood in an ancient way. Rosmini began his extensive essay Dell'idea della sapienza with an epigraph taken from Titus Flavius Clement's Stromata: "Kyria-hē sophia tēs philosophias" ("Wisdom is the queen of philosophy”) (Rosmini 2004, p. 111). ${ }^{11}$ This epigraph shows his sympathy with Clement's view on the providential and propaedeutic role of Greek philosophy in relation to

\footnotetext{
${ }^{9}$ It is noteworthy that Rosmini began his essay on the origin of ideas with the epigraph "Principium, qui et loquor vobis" ("The beginning, who also speak unto you") from the Gospel according to John 8: 25 in the Vulgate version (Rosmini 2001, p. 1). This epigraph suggests a Christological interpretation of the light of the Intellect. The phrase was understood by Saint Augustine as Jesus pointing to his identity as the divine logos (divine Word).

10 Rosmini, naturally, keeps quoting The Vulgate, which relates the Greek words erchomenon eis ton kosmon to the panta anthrōpon, and not to logos-light, as in some contemporary translation.

11 The citation is from Clement (1688, p. 284).
} 
Christianity. ${ }^{12}$ In early Christianity, philosophy was consistently presented as a servant of wisdom (a resultant of knowledge and virtue), the source of which ultimately remains the "word of God on high" (Sirach 1:5) and which comes to people fully in the Incarnate Word. ${ }^{13}$ In the final part of this text, the Italian thinker recalls, drawing from Clement and Philo, the allegoric interpretation of the relation between philosophy and wisdom contained in revelation, in imitation of the relationship between the biblical figures of Haggar and Sarah in the episode from the sixteenth chapter of the Book of Genesis (Rosmini 2004, p. 210). Rosmini strongly defends the true philosophy, which reaches beyond itself, rational faith, and reason enlightened by faith.

The "Alexandrian" spirit of Russian religious philosophy can be seen even more clearly, starting from its initiator, Vladimir Solovyev, who was called, among others, the "Russian Origen." ${ }^{14}$ Admittedly, the association of Solovyev with Origen can also be interpreted in a way that is unfavorable to the author of the Lectures on Godmanhood. Georges Florovsky, critical of the achievements of the "Sophiological School," wrote about Solovyev that, in his philosophical theology, he "did not go beyond Origen" and in general remained in some sense "in the pre-Nicene era" with its "propaedeutic problems" (Florovsky 1981, p. 317). But this assessment is definitely undermined by the supersaturation of the Solovyevian deliberations with the theology of the Council of Chalcedon, the Cappadocian Fathers, and Maximus the Confessor. At the same time, it is true that Solovyev in some way resumed the task of systematizing the doctrine issued from revelation, which had been carried out in the second century by the most famous of the Christian Alexandrians. By doing so, Solovyev was returning with great boldness to ancient controversial intuitions. Like Origines Adamantius, he was a philosopher of Logos and "spiritualized" Christianity too much, although not forgetting the Incarnation, which implies "religious materialism," the rehabilitation of matter. Moreover, the roots of Russian sophiology, initiated by Solovyev, reach back to Alexandria (as Urs von Balthasar reminded in connection with the doctrine of Sergey Bulgakov), through the modern and medieval German Gnostics. ${ }^{15}$

In all, when it comes to the whole current of "philosophical Orthodoxy," it can be clearly seen that thinkers not necessarily agreeing on particular issues turn out to be mutatis mutandis continuators of both the tradition of Christian (sub specie revelationis) Platonism and the tradition of "gnosis through faith," i.e., of "philosophy as the fruit of intellectual development of the content of faith" (Swieżawski 2000, p. 287). Christian Alexandrians wanted a "real gnōsis," and in a similar spirit Berdyaev characterized his own philosophy and Russian religious philosophy in

\footnotetext{
12 See: Rosmini (2004, p. 144, note 92). Here, Rosmini approvingly quotes Clement's Stromata L, $\S$. 6-7 in connection with his reflection on Plato's metaphysical teaching.

13 "Eternal wisdom, which is one, utterly simple, subsistent and living" (Rosmini 2004, p. 196).

14 This term is found in the title of one of the first studies on Solovyev's auvre, published in different installments in the Kharkiv periodical Vera i razum two years after the thinker's death. For a contemporary edition of this work, see Nikol'skiy (2000). Aleksey Losev protests against ascribing origenism to Solovyev and generally against alleged ideological relationships with the author of Peri archon (see: Losev 1983, pp. 60-67).

15 See: Klinger (1983, p. 297).
} 
general as "orthodox gnosis." ${ }^{16}$ And it is interesting that Saint Augustine, who is the link between the Alexandrian Christian spiritualism of Origen, Clement, and the later tradition of the Catholic West, also appears to be the joint inspiration for the Eastern and Western continuation of the Neo-Platonic tradition of "philosophizing within faith" (Bouyer 1988, p. 106). Russian religious philosophy has often been presented one-sidedly as a peculiar continuation of the Byzantine intellectual heritage (see: Evdokimov 1988, p. 83). But Evdokimov, sketching a vision of this peculiarity (confronted with the specificity of Western thought), cited the maxim Deum et animam scire cupio, derived from Augustine's Soliloquies, as a clear illustration of the Russian philosophical orientation (Evdokimov 1988, p. 85). The main authority of Latin Patristics, notwithstanding some reservations about his doctrine, not only remains largely "familiar" to Orthodoxy (see: Seliverstov 2002, pp. 10-11), but also a kindred soul in relation to the Neo-Romantic "Russian religious and philosophical Renaissance." 17

Russian religious philosophers certainly sincerely referred (with some ambivalence in the case of Berdyaev) to the tradition of the Greek Church fathers. However, they turned to that Patristic tradition in a secondary way, initially drawing from the sources of Neo-Platonic Christian "logism" through the doctrines of Schelling, Franz von Baader, Jakob Böhme, and Nicholas of Cusa. These Western thinkers, in turn, remained indebted to the theological, philosophical, and mystical teachings of Meister Eckhart, ultimately derived from the spirit of Augustine's thought, affecting the Latin Middle Ages. Fascination with the Middle Ages, specifically the Romanesque pre-Renaissance from the twelfth to the fourteenth centuries, was quite common in the culture of the Silver Age. Poets and writers of this period, inspired by Solovyev, discovered their spiritual kinship with Victorines, Franciscanism, and Dante Alighieri. The Russian mentality of the Silver Age combined an exemplary symbolism and mystical sensitivity with a humanistically and existentialistically tainted personalism, as well as with a predilection for historiosophy. In light of this, Russian religious philosophy appears to belong to the tradition initiated by the author of Confessiones himself and is like a renewed "Neo-Patristics in the context of the modern world" (Evdokimov 1988, p. 93). After all, Augustine anticipated the features of the modern mentality without breaking with the tradition of the living logos. Philosophers who oppose post-Cartesian "epistemologism" are often following Augustine's trail without even knowing it. By reconciling the epistemological starting point of modern philosophy with ontological realism, they put the cogito back on the track from which it should never have fallen. As a contemporary commentator reminds us: "In Augustine, the problem of knowledge and of its reliability has always been associated with theologically-conscious ontology. One can never speak here, in the Cartesian style, about God and about the nature of thinking

\footnotetext{
${ }^{16}$ On this, see: Pfleger (1968, p. 279). Of course, in Berdyaev's Filosofija svobody (Philosophy of Freedom), we find a clear distinction between gnosis in a heterodox sense, e.g., Valentinian-which is in fact a refined rationalism in the disguise of mysticism - and Christian gnosis that is not bold, luciferic "knowledge," but a humble way of "gaining" truth through evangelic childhood of the heart in relation to God.

17 As Elmar Salman recalls, Romanticism was a period of particular revitalization of Augustinian NeoPlatonism. On this, see Salman (2004, p. 342).
} 
separately" (Seliverstov 2002, p. 13). In Augustine's thought, the coupling of the ontology of the self with the problem of cognition opened the door for a new gnoseology grounded in the apperception of cogitatio. Yet, unlike in Modernity, it was not a radical separation of the res cogitans and the res extensa; "the unity of the meaning of what exists" was preserved (Seliverstov 2002, p. 14).

Apart from the indirect influences of Augustinism via Romantic philosophy, direct inspirations from the thought of the bishop of Hippo are also visible in Russian religious philosophy. Evgenii Troubetzkoy was involved in research on Augustine's work, and Troubetzkoy's metaphysics of cognition was clearly close to Augustine's thought, emphasizing the dependence of the mind on the intuition of truth as the objective meaning of our experiences. By demonstrating, on the basis of the aforementioned dependency of the mind on the truth, that there must be absolute consciousness that contains that truth (as certain intellectual content), Troubetzkoy formulated his own version of the Augustinian noological argument for the existence of God. The thought of the Russian philosopher follows a very similar path as that of Augustine's reflections in the twelfth book of De libero arbitrio, and Trubetzkoy's assertion about the undeniable character of our common intuition of truth-meaning is summarized in the sentence of the bishop of Hippo from his tract De vera religione: "in interiore homine habitat veritas" ("in the inward man dwells truth") (Augustini 1775, p. 97).

In turn, Rosmini's Augustinism is unquestionable, although this thinker also remained-perhaps paradoxically_an admirer of the achievements of Thomas Aquinas. However, Rosmini tried to reconcile Thomas's thought with the legacy of Augustine, and extracted from the achievements of the angelic doctor, undoubtedly gravitating toward Aristotelianism, the Neo-Platonic component present in it. The nineteenth-century thinker thus anticipated later research showing that Thomas Aquinas's Aristotelianism remained on many points, as Sofia Vanni-Rovighi, an Italian expert on the subject, put it, "heavily contaminated with Neo-Platonic elements and strongly adapted to the Christian perspective" (Vanni-Rovighi 1978, pp. 200-201). In particular, Rosmini drew attention-contrary to the stereotypical reading of Thomism - to the significant moment when Aquinas broke with the Aristotelian principle nihil est in intellectu quod non prius fuerit in sensu (nothing is in the intellect that is not first in the senses), for Aquinas acknowledged the presence of an innate element in the human mind, namely the lumen intellectus agentis (the light of the active intellect), referred to as the parvum lumen intelligibile, quod est nobis connaturale (the little intelligible light that is connatural to us) (Aquinas 1568, p. 136). This component of innatism and illumination (including virtual knowledge of universal first principles) coexisted in Thomas's view with an empiricist approach to knowing the species of things. ${ }^{18}$ For Aquinas, the belief in the original illumination of the intellect is based on the exegesis of statements from the prologue of the Gospel of John about the divine word-the true light. ${ }^{19}$

Thus, inspirations derived from Thomas, albeit not from Thomism, did not interfere with Rosmini's fundamental Augustinianism. The twentieth-century restorer

18 For an article by a contemporary researcher discussing these issues, see: Percivale (1999).

19 Cf. Aquinas (1952), c. I, lect. 5. 
and creative continuator of his thought, Michele Federico Sciacca (1908-1975), also consciously placed himself in the current of Augustinism, understood as

the desire to learn first and foremost two things: God and the soul, my soul who loves God, who seeks God. Hence, it is Christian humanism and spiritualism-with the central position of the question of the human soul in relation to God, who speaks in it; discovery of permanence of man and things; discovery of the meaning of creation, understood as such in the perpetual pursuit of the Creator-and therefore, the deepest, inner meaning of transcendence (Sciacca 1950, p. 27)

Italian spiritualism as a type of "eternal Augustinism" "20 was "a metaphysics of the interior, centered on truth" (Mondin 1998, 727). This realistic metaphysics, built on the basis of transcendent truth residing in the depths of the human mind (in interiore homine), ${ }^{21}$ was supposed to "absorb in itself two opposite metaphysics of 'being' and of 'thought,' conserving for thought and being all their validity and positivity" (Sciacca 1950, p. 25).

\section{Conclusion}

The theoretical affinity between Russian and Italian ontologism, not as surprising as it might seem, ${ }^{22}$ is a testimony to the vitality of the paradigm of Christian Neo-Platonism in Western culture (to which belongs, contrary to all appearances, the philosophizing Russia). It is a testimony to its subtle but indelible intuition of the Absolute, the intuition which remains a constituting factor of the intellect. This metaphysics of cognition, leading to "mystical realism," was modified by the biblical awareness of the transcendence of the source of existence. Therefore, Rosmini claimed that in lumen naturale rationis there is "something divine," 23 although not God himself (intangible in his nature). This incisive distinction seems analogous to the distinction unknown to Rosmini between the essence of God and His energies in the mystical gnoseology of Saint Gregory Palamas, which was applied to the general theory of knowledge by Russian thinkers. Forgoing this distinction would result in a disparity between ontologism and the dogmatic tradition of the Church (both Eastern and Western) and the worldview of the Bible, according to which "no one has ever seen God" (John 1: 18). The Absolute is not cognized as an object. However,

\footnotetext{
${ }^{20}$ Term used by Filippo Piemontese in the title of his book La "veritas" agostiniana e l'agostinismo perenne (1963).

21 So, according to the biblical vocabulary, in the "heart."

22 In his already cited article about Rosmini, Ern wrote in terms of an "unexpected" (neozhidannoe) relationship (Ern 1915, p. 250), and a contemporary researcher refers to the affinity between these two thinkers as "unanticipated" (Azzaro Pulvirenti 2006).

${ }^{23}$ Cf. The suggestive title of one of Rosmini's works: Del divino nella natura (On the Divine in Nature) (Rosmini 1991).
} 
orthodox ontologism is about the "non-objectified experience of God," which is evidenced by the "non-objectified grasp of existence" by the human intellect (see: Keller 2004, p. 1106). To paraphrase a statement from Acts (17: 27-28), we can say that we not only "live and move and have our being," but also think "in God," enveloped by His presence, embraced by His influence-that the Absolute "is not far from" our minds. His "crepuscule" (as Rosmini would say), the glow of intelligibility, is constantly stroking our consciousness.

\section{Translated by Katarzyna Popowicz and revised by Frédéric Tremblay.}

Open Access This article is licensed under a Creative Commons Attribution 4.0 International License, which permits use, sharing, adaptation, distribution and reproduction in any medium or format, as long as you give appropriate credit to the original author(s) and the source, provide a link to the Creative Commons licence, and indicate if changes were made. The images or other third party material in this article are included in the article's Creative Commons licence, unless indicated otherwise in a credit line to the material. If material is not included in the article's Creative Commons licence and your intended use is not permitted by statutory regulation or exceeds the permitted use, you will need to obtain permission directly from the copyright holder. To view a copy of this licence, visit http://creativecommons.org/licen ses/by/4.0/.

\section{References}

Alighieri, D. (1858). La Divina commedia. Palermo: Officio Tipografico Lo Bianco.

Anderson, W. (2010). Dante the Maker. New York: S4N Books.

Aquinas, T. (1568). Summa contra gentiles. Quatuor libris comprehensa. Antuerpiae: In Ædibus Viduæ \& hæredum Ioannis Stelsij.

Aquinas, T. (1952). Super Evangelium S. Ioannis lectura. Taurini, Romae: Marietti.

Augustini, S. A. (1775). Liber de vera religione. Placentiæ: Apud Josephus Tedeschi.

Azzaro Pulvirenti, R. (2006). Ern e Rosmini: Una sorprendente familiarità interiore. Torino: Trauben.

Berdyaev, N. (1907). Sub specie aeternitatis: Opyty filosofskie, social'nye i literaturnye (1900-1906). Sankt-Peterburg: Izdanie M. V. Pirozhkova.

Bouyer, L. (1988). Cosmos: The World and the Glory of God. Transl. by P. de Fontnouvelle, Petersham, Massachusetts: St. Bede Publications.

Clement of Alexandria [Clementis Alexandrini] (1688). Opera graee et latine. Coloniæ: Jeremiam Schrey \& Heinricum Joh. Meyerum.

Ern, V. F. (1911). Bor'ba za Logos: Opyty filosofskie i kriticheskie. Moskva: Izdatel'stvo Put'.

Ern, V. F. (1914). Rozmini i ego teorija znanija. Moskva: Tovarishchestvo tipografii A. I. Mamontova.

Ern, V. F. (1915). Mesto Rozmini w istorii filosofii. Voprosy filosofii i psikhologii, vol. 127, no. 2, III-IV, pp. 242-250.

Ern, V. F. (1916). Filosofija Dzhoberti. Moskva: Pechatnja A. Snegirevoj.

Ern, V. F. (2016). Vladimir Ern's Philosophy of Eros and Logos (Excerpts from Ern's Struggle for Logos). Transl. by Eugene Pustoshkin, Integral Leadership Review, vol. 16, no. 1.

Evdokimov, P. (1988). La Connaissance de Dieu selon la tradition orientale. Edition Desclée de Brouwer. Florovsky, G. (1981). Puti russkogo bogoslovija. Vtoroe izdanie. Paris: YMCA-Press.

Hadot, P. (1981). Exercices spirituels et philosophie antique. Paris: Études Augustiniennes.

Jaeger, W. (1985). Early Christianity and Greek Paideia. Cambridge, Massachusetts: Harvard University Press.

John Paul II. (1998). Encyclical Letter Fides et ratio of the Supreme Pontiff John Paul II to the Bishops of the Catholic Church on the Relationship Between Faith and Reason. Libreria Editrice Vaticana.

Keller, A. (2004). Ontologism. In: Karl Rahner (ed.), Encyclopedia of Theology: A Concise Sacramentum Mundi, Mumbai-London: St Pauls - Burns \& Oates. 
Klinger, J. (1983). Dwie postacie prekursorów prawostawnej odnowy (pp. 270-302). O istocie prawosławia, Warsaw: Instytut Wydawniczy Pax.

Krienke, M. (2006). Podmiot i istnienie. Refleksje and nowożytnością myśli Antonia Rosminiego. Transl. by P. Borkowski, Człowiek w Kulturze, no. 18, pp. 43-59.

Losev, A. (1983). Vl. Solov'ev. Moskva: Mysl'.

Mazurek, S. (2008). Rosyjski renesans religijno-filozoficzny. Próba syntezy. Warsaw: Wydawnictwo Instytutu Filozofii i Socjologii PAN.

Mondin, B. (1998). Storia della metafisica (Vol. 3). Bologna: Edizioni Studio Domenicano.

Nikol'skiy, A. A. (2000). Russkiy Origen XIX veka. Vl. Solov'ev. Sankt-Petersburg: Nauka.

Pelikan, J. (1985). Jesus Through the Centuries: His Place in the History of Culture. New Haven and London: Yale University Press.

Percivale, F. (1999). Tommaso rivisitato. Rivista rosminiana, vol. 93, no. 2, pp. 197-225.

Pfleger, K. (1968). Wrestlers with Christ. Transl. by E. I. Watkin, Freeport, New York: Books for Libraries Press.

Piemontese, F. (1963). La "veritas" agostiniana e l'agostinismo perenne. Milano: Edizione Marzorati.

Rosmini, A. (1883). The Origin of Ideas. Vol. 1. Transl. anonymous, London: Kegan Paul, Trench \& Co.

Rosmini, A. (1884). The Origin of Ideas. Vol. 3. Transl. anonymous, London: Kegan Paul, Trench \& Co.

Rosmini, A. (1991). Del divino nella natura. Roma: Città Nuova.

Rosmini, A. (2001). A New Essay Concerning the Origin of Ideas. Vol. 1. Transl. by Robert A. Murphy, Durham: Rosmini House.

Rosmini, A. (2004). Introduction to Philosophy. Volume 1: About the Author's Studies. Transl. by Robert A. Murphy, Durham: Rosmini House.

Salman, E. (2004). Intuizione dell'infinito - conoscenza del mondo. In C. Aparicio Valls, C. Dotolo, G. Pasquale (eds.), Sapere teologico e unità della fede: Studi in onore del Prof. Jared Wicks, Roma: Editrice Pontificia Università Gregoriana (pp. 335-347).

Sciacca, M. F. (1950). Filosofia e metafisica. Brescia: Morcelliana.

Seliverstov, V. L. (2002). Avgustin v russkoj intelektual'noj tradicii. In R. V. Svetlov \& V. L. Seliverstov (Eds.), Avgustin: pro et contra (pp. 8-19). Izdatel'stvo Russkogo Khristianskogo gumanitarnogo instituta: Sankt-Petersburg.

Sivak, A. F. (2007). Rosmini nella filosofia russa: Rassegna degli scritti di Vladimir Ern sul pensiero rosminiano. Rivista Rosminiana, CI, I, pp. 25-60.

Solovyev, V. (1937). God, Man and the Church: The Spiritual Foundations of Life. Transl. by Donald Attwater, Cambridge, England: James Clarke.

Swieżawski, S. (2000). Dzieje europejskiej filozofii klasycznej. Warsaw-Wrocław: Wydawnictwo Naukowe PWN.

Tresmontant, C. (1953). Essai sur la pensée hébrä̈que. Paris: Editions du Cerf.

Troubetzkoy, E. N. (1994). Smysl žizni. Moskva: Izdatel'stvo Respublika.

Vanni-Rovighi, S. (1978). Studi di filosofia medievale: Secoli XIII e XIV. Milano: Vita e Pensiero.

Walicki, A. (2005). Zarys myśli rosyjskiej. Od Oświecenia do renesansu religijno-filozoficznego. Wyd. Uniwersytetu Jagiellońskiego.

Publisher's Note Springer Nature remains neutral with regard to jurisdictional claims in published maps and institutional affiliations. 